\title{
Vliv sedimentačního prostředí na magnetickou susceptibilitu přelivových sedimentů nivy Moravy ve Strážnickém Pomoraví
}

\author{
Effects of sedimentation environment on magnetic susceptibility of floodplain sediments \\ in the Strážnické Pomoraví region
}

Jaroslava Ježková, Zdeněk Máčka 马

Geografický ústav, PřF, Masarykova univerzita, Kotlářská 2, 61137 Brno

\section{Key words:}

Floodplain sediments, magnetic susceptibility, industrial contamination, depositional rate, the Morava River

$\Xi$ macka@sci.muni.cz

Editor:

Milan Geršl

\begin{abstract}
Four profiles in different sedimentary environments - natural levee, proximal floodplain, distal floodplain, oxbow lake - were sampled to obtain magnetic susceptibility (MS), grain size, organic matter content (LOI) and $p H$. Relationships between selected parameters $\left(\chi_{l p}\right.$ $\left.D_{50}, L O I, p H\right)$ were analysed by means of statistical analysis (linear regression, PCA, factor analysis). Principal goal was to investigate how character of individual sedimentary environments and their distance from the active river channel is reflected in the magnetic signal of overbank deposits. A decrease in the magnetic signal with increasing distance from the river channel was shown, confirming that fluvial deposition is a major factor of contamination of floodplain sediments by anthropogenic magnetic particles. The base of elevated values of MS (levee: $80 \mathrm{~cm}$, proximal floodplain: $30 \mathrm{~cm}$ ) probably corresponds to the turn of the $19^{\text {th }}$ and $20^{\text {th }}$ century and the strongest magnetic signal (levee: $32.5 \mathrm{~cm}$, proximal floodplain: $5 \mathrm{~cm}$ ) belongs to the 1980s. Statistically significant relationships were found between: $\chi_{l f}$ and LOI (direct dependence), LOI and $D_{50}$ (indirect dependence), $p H$ and $D_{50}$ (direct dependence) when data from all profiles were analysed together.
\end{abstract}

\section{Úvod}

Dynamika sedimentačního prostř̌edí řičních niv je výsledkem komplexu faktorů, mezi které patří např́íklad geologická stavba a reliéf povodí (Wierzbicki et al. 2018), konektivita uvnitř fluviálního systému (Faust, Wolf 2017) nebo klimatické změny (Asselman et al. 2003). V řadě oblastí se dominantním faktorem současnosti staly zásahy člověka, jak v ploše povodí, tak v samotných korytech a nivách (de Moor et al. 2008). Předkládaný příspěvek se věnuje problematice nejmladších přelivových uloženin nivy Moravy ve Strážnickém Pomoraví. Různými aspekty vývoje širší oblasti moravní nivy na Hodonínsku se dosud zabývala celá řada autorů (Petrová et al. 1998; Havlíček et al. 2008; Kadlec et al. 2009; Nováková 2009; Grygar et al. 2010; Brázdil et al. 2011; Matys Grygar et al. 2011, 2012). Ukládání přelivových sedimentů je v současnosti na Strážnicku do značné míry určováno antropogenními faktory. V prvé řadě je to systém protipovodňových hrází vybudovaný před II. světovou válkou, který zmenšil rozsah povodňových inundací na cca $25 \%$ původní plochy (Máčka, Kadlec 2016). Druhým faktorem je nadměrné zahloubení koryta vyvolané inženýrskými úpravami, které způsobuje, že do nivy se rozlévají teprve povodně s pětiletým a vyšším intervalem opakování (Brázdil et al. 2011).

Cílem studie bylo porovnat vybrané vlastnosti přelivových sedimentů (resp. fluvizemí, které se $\mathrm{z}$ nich vyvíjejí) v sedimentačních prostředích různého 


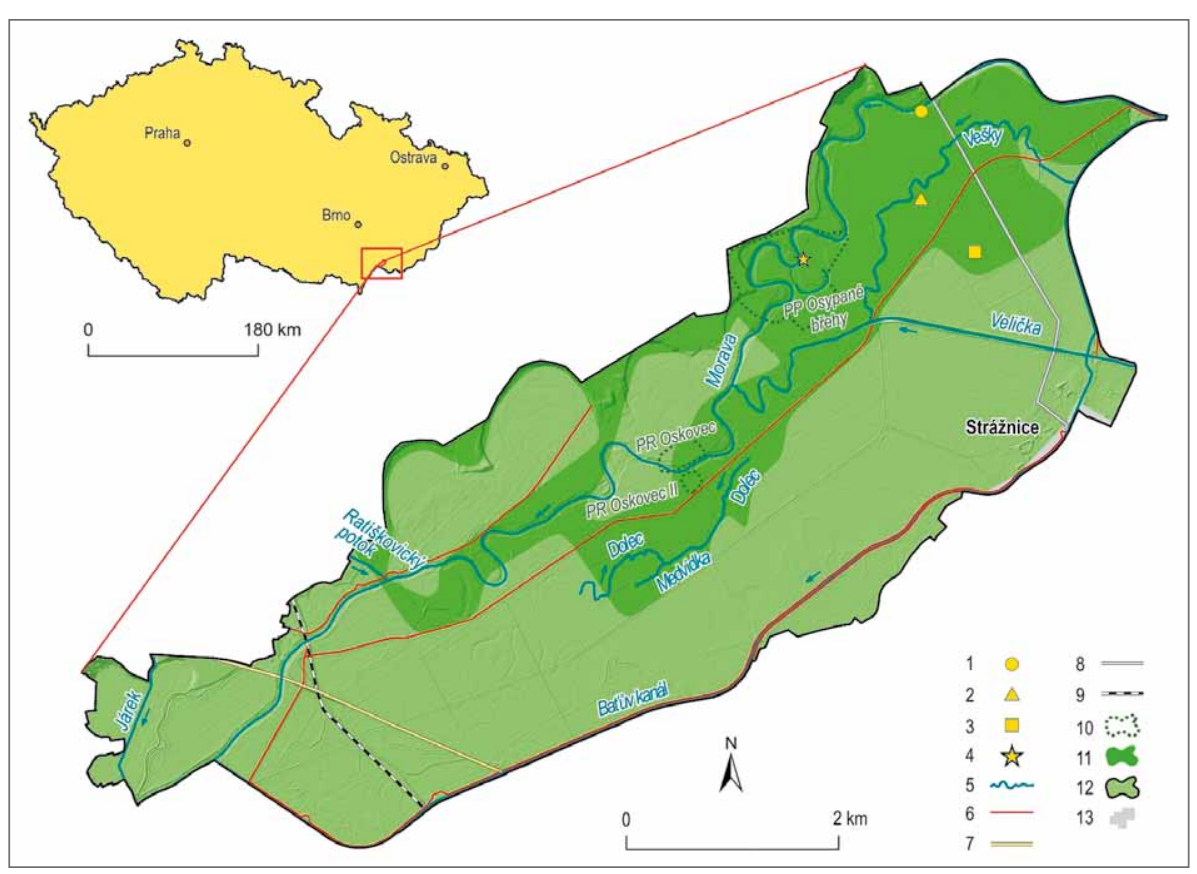

Obr. 1: Poloha zkoumaných sedimentárních profilů $\mathrm{v}$ nivě řeky Moravy ve Strážnickém Pomoraví. 1 - břehová nátrž; 2 - předhrází; 3 - zahrází; 4 - aluviální zátka; 5 - vodní toky; 6 - protipovodňové hráze; 7 - silnice I. trŕ́dy; 8 - silnice II. třídy; 9 - železnice; 10 - maloplošná zvláště chráněná území; 11 - lesy; 12 - PřP Strážnické Pomoraví; 13 - sídla.

Fig. 1: The location of the investigated sedimentary profiles in the Morava River floodplain in Strážnické Pomoraví. 1 - exposed bank; 2 - proximal floodplain; 3 - distal floodplain; 4 - alluvial plug; 5 - rivers; 6 flood defence dykes; 7 - 1st class road; 8 - 2nd class road; 9 - railway; 10 - small-scale specially protected areas; 11 - forests; 12 - The Natural Park Strážnické Pomoraví; 13 - towns.

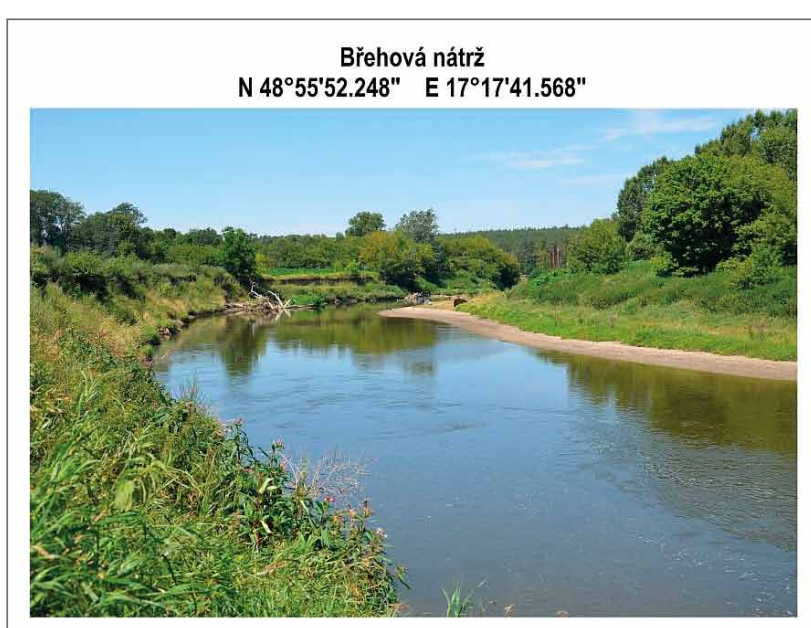

Předhrází
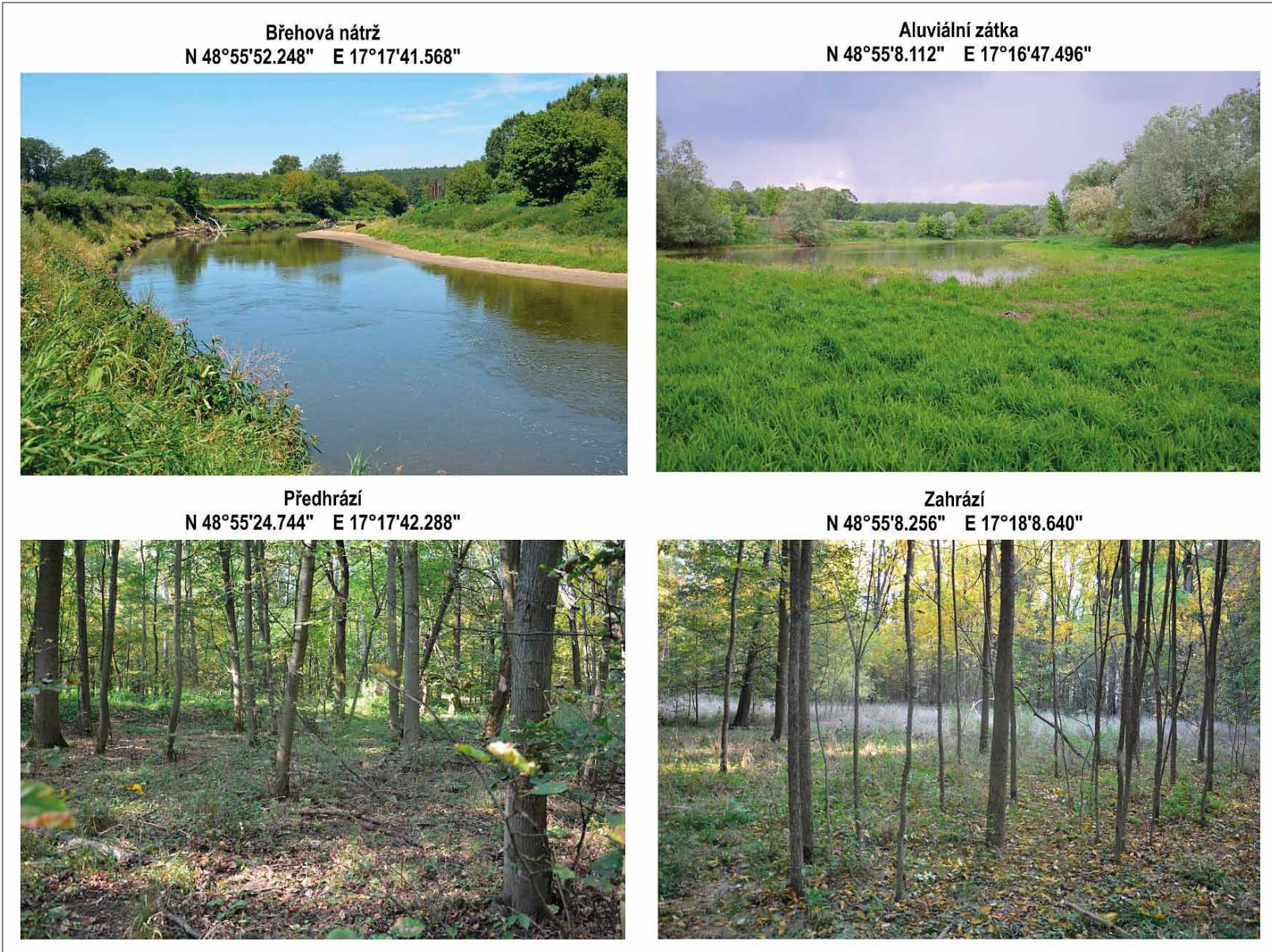

Obr. 2: Okolí míst odběru sedimentů.

Fig. 2: Surroundings of the sampling sites.

charakteru. Jednalo se o magnetickou susceptibilitu (MS), zrnitost, obsah organické hmoty (LOI) a půdní reakci $(\mathrm{pH})$. Východiskem byl předpoklad, že ve svrchních částech sedimentárních profilů bude zvýšený magnetický signál v důsledku jejich kontaminace magnetickými částicemi antropogenního původu (především v souvislosti se 
zprovozněním tepelné elektrárny v Hodoníně a zvýšením automobilové dopravy po II. světové válce). Pro porovnání byla vybrána sedimentační prostředí agradačního valu (břehová nátrž), proximální nivy (předhrází), distální nivy (zahrází, v současnosti bez záplav) a aluviální zátky v odškrceném meandru (obr. 1 a 2). Mocnost prrípovrchové vrstvy se zvýšenými hodnotami magnetické susceptibility lze použít jako proxy ukazatel nejmladší agradace nivy po začátku průmyslové revoluce (Desenfant et al. 2004;
Knab et al. 2006; Costanzo-Álvarez et al. 2017). Zrnitost, LOI a pH slouží jako doplňkové parametry pro dokreslení charakteru sedimentace a pedogeneze na lokalitách profilů.

\section{Metodika}

Poloha analyzovaných profilů byla zvolena v různé vzdálenosti od aktivního koryta tak, aby se lišila frekvencí zaplavování povodněmi a rychlostí agradace.

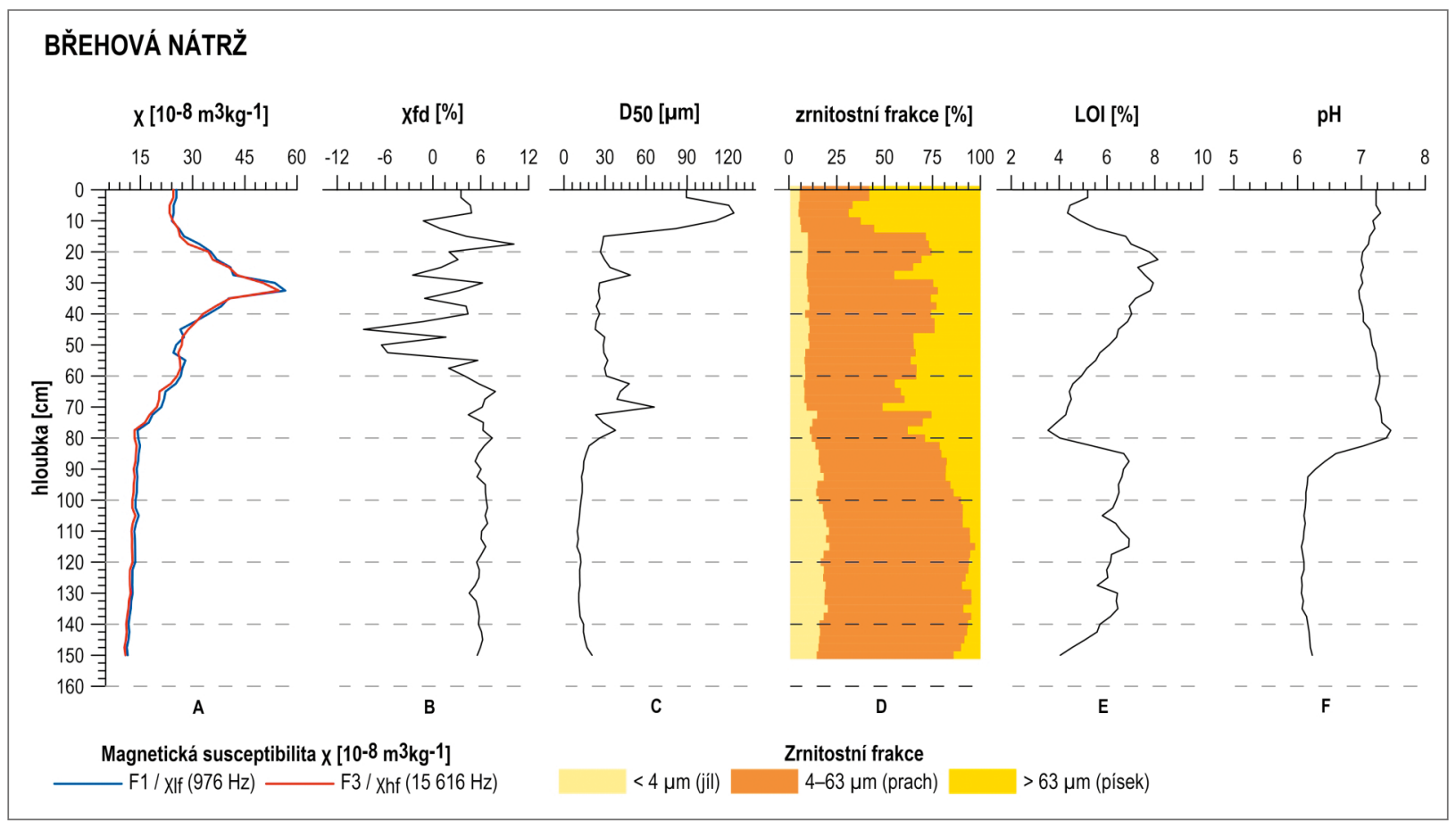

Obr. 3: Naměřené fyzikální a fyzikálně-chemické parametry v profilu břehové nátrže.

Fig. 3: The measured physical and physico-chemical parameters in the profile of exposed bank.

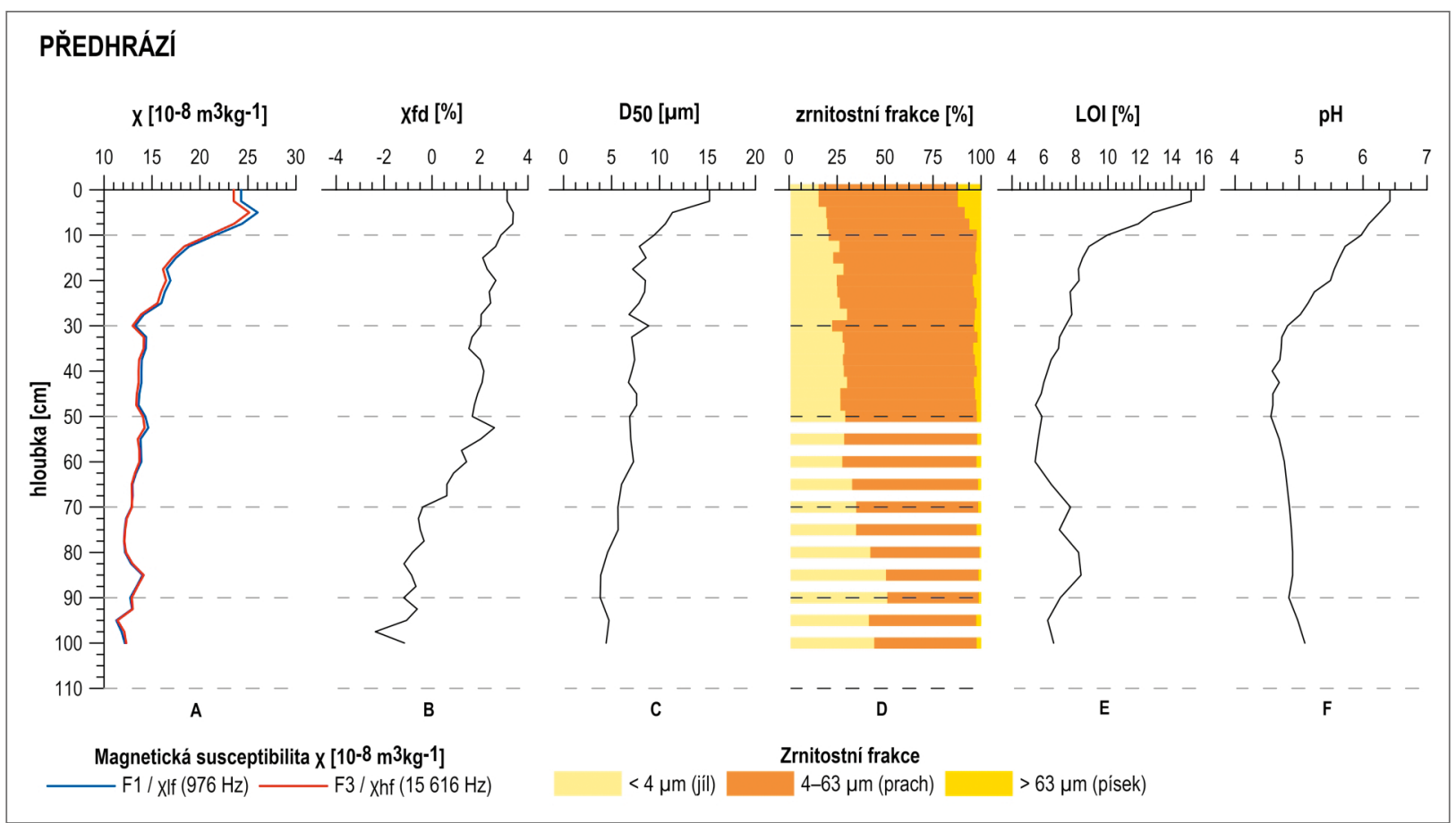

Obr. 4: Naměřené fyzikální a fyzikálně-chemické parametry v profilu z předhrází.

Fig. 4: The measured physical and physico-chemical parameters in the profile of proximal floodplain. 
Ve čtyřech kopaných sondách byly odebrány vzorky po $2,5 \mathrm{~cm}$ do hloubky $1,5 \mathrm{~m}$ u břehové nátrže, do hloubky $1 \mathrm{~m} \mathrm{u}$ ostatních profilů. Po odstranění rostlinných makrozbytků byly vzorky vysušeny při teplotě $105^{\circ} \mathrm{C}$, a následně kvartovány na požadované množství. Magnetická susceptibilita byla měřena na vzorcích o hmotnosti $10 \mathrm{~g}$ na kappa můstku Agico MFK1-FA na frekvencích 976 a $15616 \mathrm{~Hz}$. Následně byla vypočtena frekvenčně závislá magnetická susceptibilita podle vztahu Dearing (1996):

$$
\chi_{f d} \%=\left(\frac{X_{l f}-X_{h f}}{X_{l f}}\right) * 100[\%]
$$

kde $\chi_{\mathfrak{l f}} \chi_{\mathrm{hf}}$ je magnetická susceptibilita měřená za nižší a vyšši frekvence magnetického pole. Zrnitostní složení vzorků bylo stanoveno metodou laserové difrakce na zař́zení BetterSizer S3 Plus. Stanovení obsahu organické hmoty metodou ztráty žíháním (loss on ignition, LOI) bylo provedeno v muflové peci LAC LMH 07/12. Pro určení pH byl využit laboratorní multimetr WTW inoLab Multi 740 s pH elektrodou WTW SenTix 41.

\section{Fyzikální a fyzikálně-chemické vlastnosti přelivových sedimentů Magnetická susceptibilita přelivových sedimentů}

Průběh hodnot magnetické susceptibility, zrnitosti, obsahu organické hmoty a půdní reakce v jednotlivých profilech znázorňují obrázky 3 až 6 . Průběh magnetické susceptibility měřené za nižši frekvence magnetického pole $\left(\chi_{\mathrm{If}}\right)$ u břehové nátrže a předhrází je víceméně analogický. Směrem od báze obou profilů se vyznačuje téměř neměnnými hodnotami, které výše přecházejí v magneticky posílenou vrstvu s nejsilnějším magnetickým signálem (obr. 3A a 4A). Pozadové hodnoty, na něž má největší vliv litologie daného podloží, dosahují u břehové nátrže $\mathrm{v}$ průměru $12,71 \times 10^{-8} \mathrm{~m}^{3} \mathrm{~kg}^{-1}(80-150 \mathrm{~cm})$, u předhrází $13,19 \times 10^{-8} \mathrm{~m}^{3} \mathrm{~kg}^{-1}(30-100 \mathrm{~cm})$. Odlišná je však hloubka, v níž mají sedimenty nejsilnější magnetický signál (břehová nátrž: $32,5 \mathrm{~cm}$; předhrází: $5 \mathrm{~cm}$ ), což je dáno rychlejší depozicí $\mathrm{v}$ prrípadě agradačního valu. Rovněž hodnoty $\chi_{\mathrm{If}}$ jsou vyšší u břehové nátrže (max. $\left.56,61 \times 10^{-8} \mathrm{~m}^{3} \mathrm{~kg}^{-1}\right)$ ve srovnánís s proximální nivou (max. 26,01 $\left.\times 10^{-8} \mathrm{~m}^{3} \mathrm{~kg}^{-1}\right)$. V distální nivě (zahrází) je patrný víceméně podobný trend, ale ve srovnání s předchozími dvěma profily zdaleka ne tak výrazně vyjádřený (obr. 5A). Profil v tomto prostředí se vyznačuje hodnotami kolem $9,51 \times 10^{-8} \mathrm{~m}^{3} \mathrm{~kg}^{-1} \mathrm{v}$ hloubkách $70-100 \mathrm{~cm}$, hodnotami s průměrem $12,49 \times 10^{-8} \mathrm{~m}^{3} \mathrm{~kg}^{-1} \mathrm{v}$ hloubce $20-70 \mathrm{~cm}$ a pozvolným nárůstem hodnot směrem $\mathrm{k}$ povrchu. Lokální maximum $\mathrm{v}$ prrípovrchové vrstvě $\mathrm{s}$ posíleným magnetickým signálem bylo zjištěno $\mathrm{v}$ hloubce $7,5 \mathrm{~cm}$ $\left(18,11 \times 10^{-8} \mathrm{~m}^{3} \mathrm{~kg}^{-1}\right)$. Magnetický signál u aluviální zátky je poměrně silný (obr. 6A), v celém profilu dosahuje průměrně $25,85 \times 10^{-8} \mathrm{~m}^{3} \mathrm{~kg}^{-1}$. Ve srovnání s ostatními prostředími byly vysoké hodnoty $\chi_{\mathrm{If}}\left(\mathrm{až} 34 \times 10^{-8} \mathrm{~m}^{3} \mathrm{~kg}^{-1}\right)$ zaznamenány také ve větších hloubkách (např. $60 \mathrm{~cm}$; $87,5 \mathrm{~cm}$ aj.).

V profilech byly dále sledovány hodnoty frekvenčně závislé susceptibility, která bývá používána pro detekci jemnozrnných ferrimagnetických částic. Tento parametr je považován za vhodný prostředek pro rozlišení mezi ferrimagnetickými částicemi antropogenního původu a přirozenými ferrimagnetickými částicemi, obsahujícími superparamagnetická (SP) zrna, za jejichž vznik jsou zodpovědné pedogenní procesy. Hodnoty frekvenčně závislé susceptibility $\left(\chi_{\mathrm{fd}}\right)$ se v pozadí břehové nátrže $(80-150 \mathrm{~cm})$ pohybují v průměru kolem $5,97 \%$ (obr. 3B). Vrstva se zvýšeným magnetickým signálem $(0-80 \mathrm{~cm})$ se vyznačuje výrazně rozkolísanými hodnotami (průměr $2,80 \%$ ). V prŕípadě, že jsou opomenuty tyto fluktuace, podobné zastoupení jemnozrnných magnetických částic přirozeného původu je zřejmé také u aluviální zátky (obr. 6B). V celé hloubce profilu byly zaznamenány průměrné hodnoty cca $4,43 \%$. Proximální a distální niva mají shodný trend s rostoucí $\chi_{\mathrm{fd}}$ od báze směrem do svrchní části profilu (obr. $4 \mathrm{~B}$ a $5 \mathrm{~B})$. Zjištěný průměr $\chi_{\mathrm{fd}}$ za celé profily činí $1,10 \%$, resp. $-0,37 \%$.

\section{Zrnitost, obsah organické hmoty a půdní reakce přelivových sedimentů}

Spodní část břehové nátrže je tvořena jemnozrnějšími sedimenty s průměrnou hodnotou mediánu $12,96 \mu \mathrm{m}$, od $80 \mathrm{~cm}$ směrem výše pak je zrnitostní složení profilu více heterogenní s několika písčitými polohami (obr. 3C). Nejhrubší frakce se nachází ve svrchních $15 \mathrm{~cm}$ (průměr $92,61 \mu \mathrm{m})$. Průměr mediánu pro celý profil $\mathrm{v}$ předhrází a v zahrází je téměř shodný, $7,39 \mu \mathrm{m}$, resp. 7,67 $\mu \mathrm{m}$ (obr. $4 \mathrm{C}$ a 5C). Medián zrnitosti u aluviální zátky vykazuje obecně nejvyšší hodnoty (až 250,20 $\mu \mathrm{m}$ v hloubce $97,5 \mathrm{~cm}$ ). Sedimenty aluviální zátky jsou zrnitostně velmi variabilní (obr. 6C), s prítomností několika písčitých poloh.

Celkově největší podíl jílovité frakce $(<4 \mu \mathrm{m})$, v průměru $32,23 \%$, je př́tomen v profilu ze zahrází (obr. 5D). Větší obsah jílu (průměr 29,84 \%) se vyskytuje také v předhrází (obr. 4D). Břehová nátrž a aluviální zátka (obr. 3D a 6D) mají shodně nízké zastoupení jílu (průměr $12,92 \%$, resp. 8,89 \%). Podíl prachovité frakce $(4-63 \mu \mathrm{m})$ je nejvyšší v předhrází (průměr 67,12 \%), nižší obsah je evidentní u břehové nátrže (průměr $62,87 \%$ ) a zahrází (průměr 55,46 \%), avšak nejnižší množství bylo zjiššěno u aluviální zátky (průměr 48,03 \%). Ta má naopak ve srovnání s ostatními prostředími největší podíl hrubé frakce $(>63 \mu \mathrm{m})$. V celém profilu je tento materiál zastoupen průměrně $43,07 \%$.

Postupný nárůst podílu organické hmoty od báze profilu břehové nátrže je stř́idán kolísáním a poklesem, po němž organického materiálu opět přibývá (obr. 3E), a to až do hloubky $22,5 \mathrm{~cm}$, kde má organická hmota nejvyšší zastoupení $(8,13 \%)$. Podíl organické hmoty $\mathrm{v}$ profilech z předhrází a ze zahrází má směrem od jejich báze protichůdnou tendenci, avšak cca od $30 \mathrm{~cm}$ se oba profily vyznačují identickým rostoucím trendem (obr. $4 \mathrm{E}$ a $5 \mathrm{E})$. Průměrné zastoupení $\mathrm{v}$ předhrází dosahuje $7,73 \%$, v zahrází $8,05 \%$. Charakter průběhu organické hmoty u aluviální zátky je shodný s křivkou $\chi_{\text {If }}$ (obr. 6E). Její vyšší obsahy v hlubších částech profilu lze přisoudit nepravidelné sedimentaci. 
Půdní reakce u břehové nátrže je zpočátku neutrální a od $82,5 \mathrm{~cm}$ výše se mění na mírně zásaditou (obr. $3 \mathrm{~F}$ ). Aluviální zátka má v celé své délce mírně zásaditou reakci (obr. 6F). U proximální nivy přechází středně kyselá reakce do mírně kyselé, a to v hloubce cca $27,5 \mathrm{~cm}$ (obr. 4F). Mírně kyselá půdní reakce $\mathrm{v}$ distální nivě je střídána středně kyselou a od $7,5 \mathrm{~cm}$ se opět vrací $\mathrm{k}$ mírně kyselé reakci (obr. 5F).

\section{Vztahy mezi měřenými parametry přelivových sedimentů}

Hodnoty měřených parametrů přelivových sedimentů ze všech čtyř profilů byly sloučeny a analyzovány jako celek prostřednictvím faktorové analýzy, analýzy hlavních komponent (PCA) a jednoduché lineární regrese za účelem sledování vztahů mezi sledovanými proměnnými.

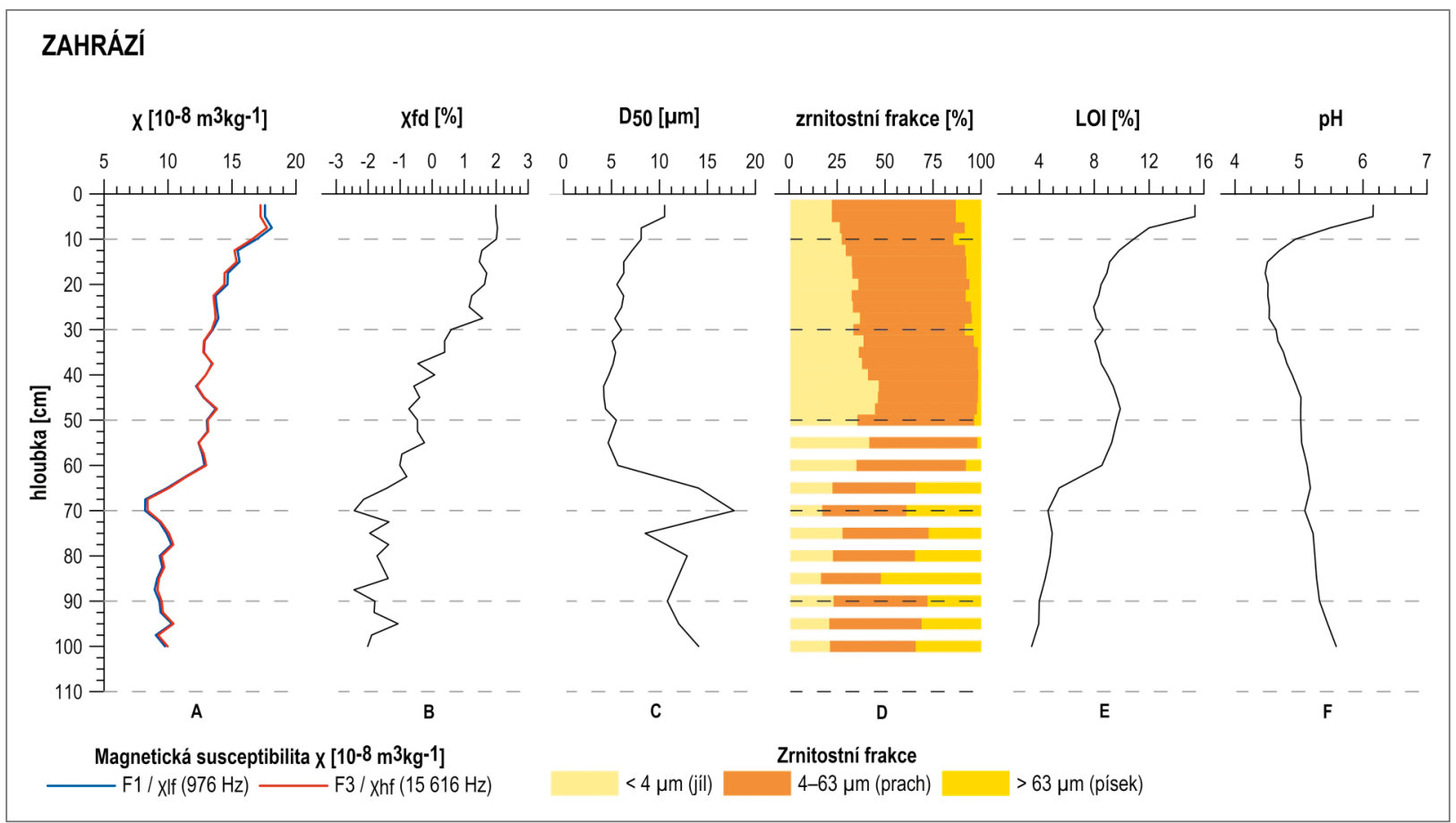

Obr. 5: Naměřené fyzikální a fyzikálně-chemické parametry v profilu ze zahrází.

Fig. 5: The measured physical and physico-chemical parameters in the profile of distal floodplain.

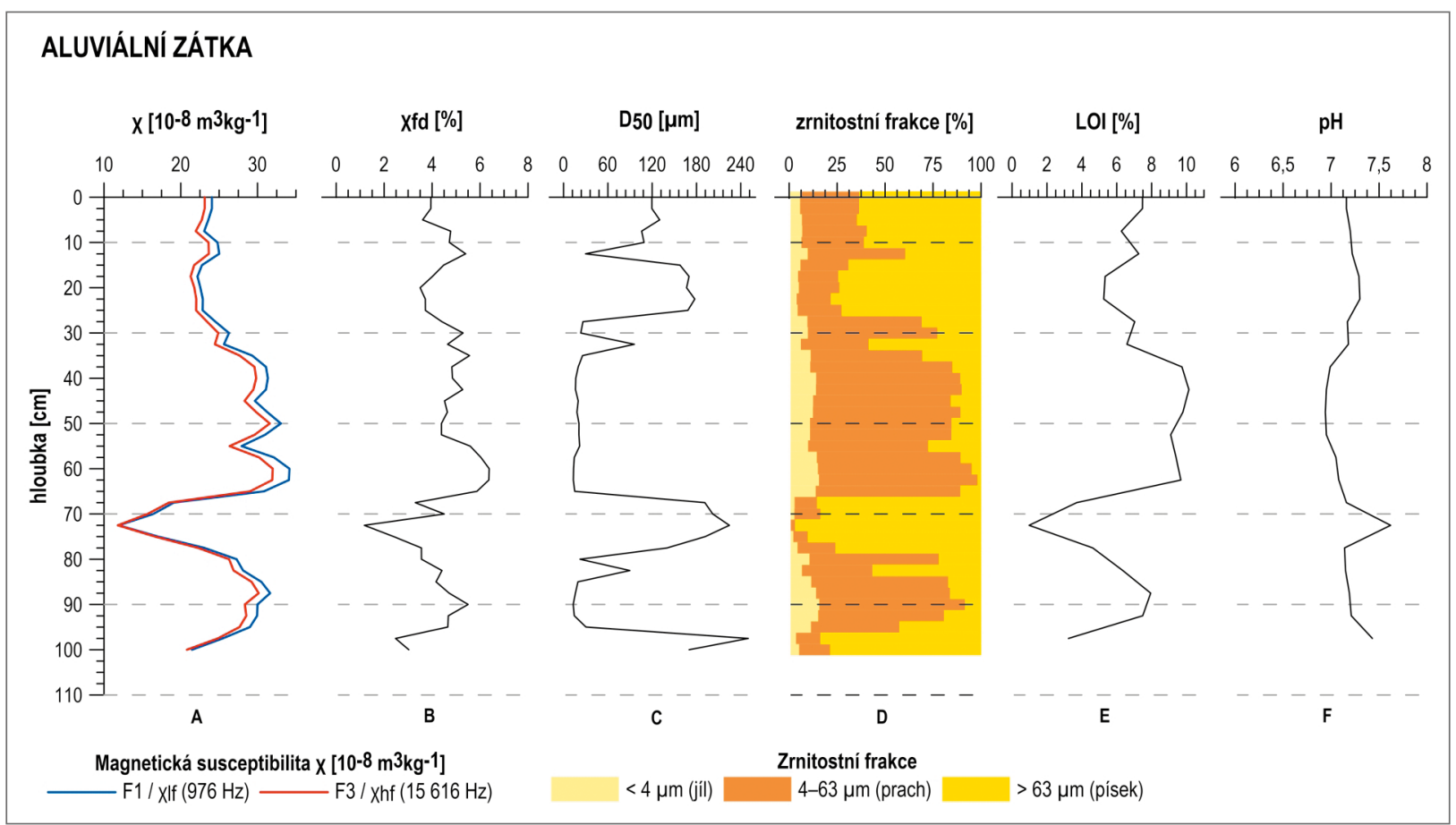

Obr. 6: Naměřené fyzikální a fyzikálně-chemické parametry v profilu aluviální zátky.

Fig. 6: The measured physical and physico-chemical parameters in the profile of alluvial plug. 


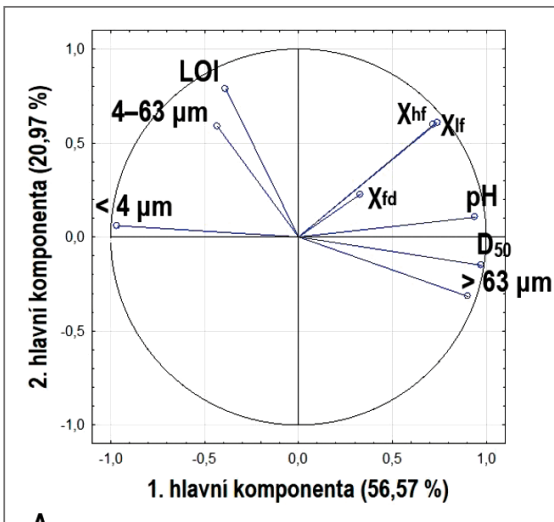

A

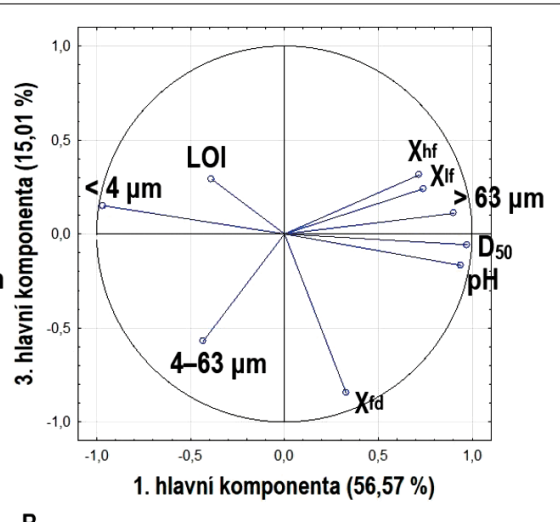

B

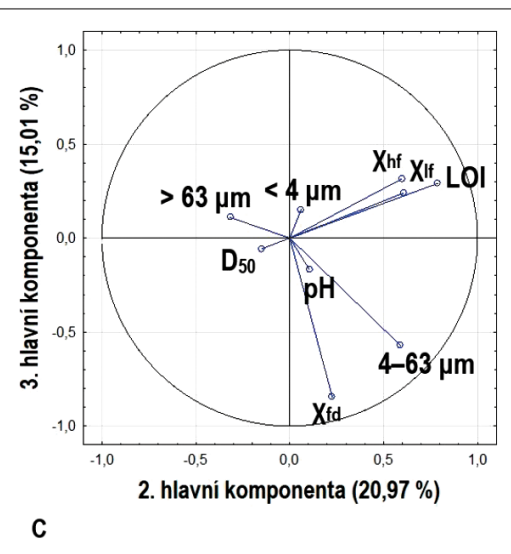

Obr. 7: Komponentní váhy (zátěže) u sloučených dat ze všech profilů (A - 1. a 2. komponenta; B - 1. a 3. komponenta; C - 2. a 3. komponenta).

Fig. 7: Component weights for combined data from all profiles ( $\mathrm{A}$ - the first and the second component; $\mathrm{B}$ - the first and the third component; $\mathrm{C}$ - the second and the third component).

V př́ípadě PCA byly uplatněny první tři hlavní komponenty, jež vysvětlují více než $77 \%$ variability dat. U první a druhé hlavní komponenty se nejméně významnou proměnnou jeví $\chi_{\mathrm{fd}}(\mathrm{obr}$.7A). Silná pozitivní korelace existuje mezi LOI a frakcí 4-63 $\mu \mathrm{m}$. Negativní korelace se projevila u $\mathrm{pH}$, mediánu zrnitosti $\left(\mathrm{D}_{50}\right)$ a frakce $>63 \mu \mathrm{m}$ na jedné straně, a nejjemnější frakce $(<4 \mu \mathrm{m})$ na straně druhé.

Při porovnání první a třetí hlavní komponenty mají nejmenší význam proměnné LOI a frakce $4-63 \mu \mathrm{m}$, u nichž se neprokázal vzájemný vztah (obr. 7B). Žádná korelace neexistuje ani mezi $\chi_{1 \mathrm{f}} \chi_{\mathrm{hf}}$ a $\chi_{\mathrm{fd}}$. Magnetická susceptibilita $\left(\chi_{\mathrm{ff}}\right.$ a $\left.\chi_{\mathrm{hf}}\right)$ naopak pozitivně koreluje $\mathrm{s} \mathrm{pH}$, $\mathrm{D}_{50}$ a frakcí $>63 \mu \mathrm{m}$.

$\mathrm{K}$ méně významným proměnným se u druhé a třetí hlavní komponenty řadí: $\mathrm{D} 50, \mathrm{pH}$ a frakce $<4 \mu \mathrm{m}$ a $>63 \mu \mathrm{m}$ (obr. 7C). Silná pozitivní korelace je evidentní mezi $X_{\mathrm{tp}} X_{\mathrm{hf}}$ a LOI, a naopak tyto veličiny téměř vůbec nekorelují $s \chi_{\mathrm{fd}}$. Vztah magnetické susceptibility a LOI $\mathrm{k}$ frakci $4-63 \mu \mathrm{m}$ je na hranici mezi velmi slabou pozitivní až téměř žádnou korelací.

Dále byla aplikována metoda jednoduché lineární regrese za účelem studia vybraných závislostí mezi fyzikálně-chemickými parametry: $\mathrm{D}_{50} / \mathrm{LOI} / \mathrm{pH}$ a $\chi_{\mathrm{lp}} \dot{ } \mathrm{D}_{50}$ a LOI; $\mathrm{D}_{50} / \mathrm{LOI}$ a $\mathrm{pH}$. Statisticky významný vztah platný pro všechna zkoumaná prostředí byl nalezen mezi: $\chi_{\text {If }}$ a LOI $\left(\mathrm{r}=0,7371 ; \mathrm{R}^{2}=0,5434\right), \mathrm{pH}$ a $\mathrm{D}_{50}\left(\mathrm{r}=0,8945 ; \mathrm{R}^{2}=\right.$ $0,8002)$ a LOI a $D_{50}\left(r=-0,4868 ; R^{2}=0,2370\right)$.

\section{Diskuze a závěr}

V rámci studia přelivových sedimentů Moravy byly zkoumány rozdíly jejich fyzikálních a fyzikálně-chemických parametrů $\mathrm{v}$ různých sedimentačních prostředích. Jednalo se o prostředí agradačního valu, proximální nivy (předhrází), distální nivy (zahrází, lokalita s vyloučeným zaplavováním) a aluviální zátky (odškrcený meandr). Vhodnými parametry pro odlišení jednotlivých prostředí se ukázaly být zejména magnetická susceptibilita a zrnitost.

Hodnoty magnetické susceptibility $\left(\chi_{\mathrm{lp}}, \chi_{\mathrm{hf}}\right)$ vykazují $\mathrm{v}$ jednotlivých profilech víceméně podobný průběh s posílenými hodnotami blíže povrchu, ovšem se zřetelně odlišnými hodnotami minim a maxim, ale také odlišnou hloubkou absolutního maxima pod povrchem. Síla magnetického signálu celkově klesá se vzdáleností od aktivního koryta. Lokality uvnitř systému hrází, kde stále může docházet k povodňovým rozlivům (agradační val, proximální niva), vykazují vyšší hodnoty susceptibility, ale zejména zřetelné zesílení magnetického signálu ve svrchních částech profilů. Výraznější maximum magnetické susceptibility u agradačního valu i jeho poloha ve větši hloubce pod povrchem odráží vyšší frekvenci zaplavování a rychlejší depozici v blízkosti aktivního koryta (obr. 3A a 4A). Zesílení magnetického signálu $\mathrm{v}$ př́povrchových částech sedimentárních a půdních profilů zaznamenali také Petrovský et al. (2000), Nováková (2009) nebo Chudaničová et al. (2016).

Zřetelná maxima magnetické susceptibility u těchto dvou profilů lze nejspíše vysvětlit př́nosem magnetických částic antropogenního původu (Petrovský, Ellwood 1999). Identifikace všech možných zdrojů magnetických částic a stanovení jejich relativního podílu při navýšení magnetického signálu, který byl zaznamenán ve svrchních částech profilů lokalizovaných $\mathrm{v}$ nivě, není jednoduchou otázkou. Jedním z důležitých zdrojů byl nejspíše provoz tepelné elektrárny spalující lignit v blízkém Hodoníně, spekulovat je možné rovněž o nárůstu automobilové dopravy v období po II. světové válce. Vzhledem k tomu, že hodnoty MS však začaly narůstat již před obdobím, kdy se mohly uplatnit ty to dva zdroje, má povaha vnosu magnetických částic do sedimentů nivy mnohem komplexnější povahu. Tomu napovídá i odlišný rozsah hodnot MS u profilu za levobřežní protipovodňovou hrází, kde nedochází k zaplavování nivy od doby dokončení hrázového systému na konci 30. let 20. stol. (obr. 5A). Specifický průběh mají hodnoty MS u aluviální zátky, které vykazují výrazné fluktuace s hloubkou. Hodnoty MS mají v tomto prrípadě zřetelnou vazbu na zrnitost materiálu, a poukazují na velkou dynamiku sedimentačního prostředí odškrceného meandru. Ta je především odrazem hydrologického režimu Moravy v době po odškrcení meandru (2006), konektivity mezi odškrceným meandrem a aktivním 
korytem a topografií sedimentačního prostoru (Ondruch et al. 2018). Uvedené skutečnosti také napovídají, že magnetické částice antropogenního původu se do nivy dostávají spíše při povodních s ukládanými plaveninami, než atmosférickým spadem.

Antropogenně zvýšené hodnoty MS lze využít jako proxy metodu datování recentních přelivových sedimentů (Nováková 2009). Rámcový odhad počátku sedimentace magneticky posílené vrstvy $\mathrm{v}$ agradačním valu, s použitím rychlosti sedimentace $\mathrm{v}$ analogických profilech (0,8 cm/rok; Kadlec et al. 2009), odpovídá období 1910-20. Podobné časové zařazení nejmladších aluviálních sedimentů uvádějí také Grygar et al. (2010), Matys Grygar et al. (2011, 2012). Vrstva s maximálními hodnotami $\chi_{\text {If }}$ pak spadá nejpravděpodobněji do období konce 70. let 20. stol., což je v zásadě v souladu s obdobím vrcholu spalovaní uhlí v 80. letech, jak uvádí Novák et al. (2003). Patrně nejspolehlivějším profilem, kterého lze využít jako sedimentárního archivu pro nepřímé určení stáří sedimentů, je předhrází. Tvoří ho materiál proximální nivy a nejsou v něm přítomny žádné písčité vložky, které by značily nepravidelnou sedimentaci, jako je tomu $\mathrm{v}$ př́ípadě agradačních valů. Příslušná agradační rychlost, která by nejlépe vystihovala charakter profilu v předhrází, je $0,23 \mathrm{~cm} /$ rok (Matys Grygar et al. 2011). Báze zvýšených hodnot $\chi_{\mathrm{If}}(30 \mathrm{~cm})$, patrně kontaminovaná vrstva, by pak byla datována přibližně do období 1880-90. Vrstva sedimentů s maximálním magnetickým signálem $(5,0-7,5 \mathrm{~cm})$ pravděpodobně dokládá přelom 80 . a 90 . let 20 . stol.

Ukládání přelivových sedimentů v nivě Moravy bylo ve 20. století ve Strážnickém Pomoraví ovlivněno vybudováním systému protipovodňových hrází, které změnily prostorovou distribuci sedimentace v nivě. Dále byla rychlost sedimentace ovlivněna klesající frekvencí zaplavování nivy, která souvisí se zahlubováním a rozširováním koryta Moravy, a to zejména v období od II. světové války. Analýza různých sedimentačních prostředí ukazuje, že uvedené změny lze detekovat i pomocí studia kontaminace sedimentů magnetickými částicemi antropogenního původu.

\section{Poděkování}

Příspěvek byl zpracován s podporou projektů Výzkum promén geografických procesů a vztahů v prostoru a čase (MUNI/A/1576/2018) a Ecopolaris (CZ.02.1.01/0.0/0.0/16 _013/0001708). Za podnětné pripomínky $k$ podobě první verze rukopisu děkujeme J. Havírovi a anonymnímu recenzentovi. 


\section{Literatura}

Asselman, N. E. M., Middelkoop, H., van Dijk, P. M. (2003). The impact of changes in climate and land use on soil erosion, transport and deposition of suspended sediment in the River Rhine. - Hydrological Processes, 17, 16, 3225-3244. https://doi. org/10.1002/hyp.1384

Brázdil, R., Máčka, Z., Řezníčková, L., Soukalová, E., Dobrovolný, P., Matys Grygar, T. (2011). Floods and floodplain changes of the River Morava, the Strážnické Pomoraví region (Czech Republic) over the past 130 years. - Hydrological Sciences Journal/Journal des Sciences Hydrologiques, 56, 7, 1166-1185. https://doi.org/10.1080/02626667.2011.608359

Costanzo-Álvarez, V., Devesa-Rey, R., Aldana, M., Barral, M. T., López-Rodríguez, D., Andrade, B. (2017). Magnetic properties of surface sediments as proxies of recent anthropogenic pollution in the Anllóns riverbed (NW Spain). - Environmental Earth Sciences, 76, 454-468. https://doi.org/10.1007/s12665-017-6785-4

de Moor, J. J. W., Kasse, C., van Balen, R., Vandenberghe, J., Wallinga, J. (2008). Human and climate impact on catchment development during the Holocene - Geul River, the Netherlands. - Geomorphology, 98, 3-4, 316-339. https://doi.org/10.1016/j. geomorph.2006.12.033

Dearing, J. A., Dann, R. J. L., Hay, K., Lees, J. A., Loveland, P. J., Maher, B. A., O‘Grady, K. (1996). Frequency-dependent susceptibility measurements of environmental materials. - Geophysical Journal International, 124, 1, 228-240. https://doi. org/10.1111/j.1365-246X.1996.tb06366.x

Desenfant, F., Petrovský, E., Rochette, P. (2004). Magnetic signature of industrial pollution of stream sediments and correlation with heavy metals: Case study from south France. - Water, Air, and Soil Pollution, 152, 1-4, 297-312. https://doi.org/10.1023/B:WATE.0000015356.88243.f0

Faust, D., Wolf, D. (2017). Interpreting drivers of change in fluvial archives of the Western Mediterranean - A critical view. Earth-Science Reviews, 174, 53-83. https://doi.org/10.1016/j.earscirev.2017.09.011

Grygar, T., Světlík, I., Lisá, L., Koptíková, L., Bajer, A., Wray, D. S., Ettler, V., Mihaljevič, M., Nováková, T., Koubová, M., Novák, J., Máčka, Z., Smetana, M. (2010). Geochemical tools for the stratigraphic correlation of floodplain deposits of the Morava River in Strážnické Pomoraví, Czech Republic from the last millennium. - Catena, 80, 2, 106-121. https://doi. org/10.1016/j.catena.2009.09.005

Havlíček, P., Kučera, Z., Vacek, M. (2008). Přírodní park Strážnické Pomoraví - Osypané břehy: zkrácení toku Moravy. - Zprávy o geologických výzkumech v roce 2007, 41, 91-92.

Chudaničová, M., Hutchinson, S. M., Hradecký, J., Sedláček, J. (2016). Environmental magnetism as a dating proxy for recent overbank sediments of (peri-)industrial regions in the Czech Republic and UK. - Catena, 142, 21-35. https://doi.org/10.1016/j.catena.2016.02.008

Kadlec, J., Grygar, T., Světlík, I., Ettler, V., Mihaljevič, M., Diehl, J. F., Beske-Diehl, S., Svitavská-Svobodová, H. (2009). Morava River floodplain development during the last millennium, Strážnické Pomoraví, Czech Republic. - The Holocene, 19, 3, 499-509. https://doi.org/10.1177/0959683608101398

Knab, M., Hoffmann, V., Petrovský, E., Kapička, A., Jordanova, N., Appel, E. (2006). Surveying the anthropogenic impact of the Moldau river sediments and nearby soils using magnetic susceptibility. - Environmental Geology, 49, 4, 527-535. https://doi.org/10.1007/s00254-005-0080-5

Máčka, Z., Kadlec., J. (2016): Strážnické Pomoraví - Holocene evolution of a unique floodplain and aeolian landforms. - In: Pánek, T., Hradecký, J. (eds): Landscapes and Landforms of the Czech Republic, 361-371, Springer.

Matys Grygar, T., Nováková, T., Mihaljevič, M., Strnad, L., Světlík, I., Koptíková, L., Lisá, L., Brázdil, R., Máčka, Z., Stachoň, Z., Svitavská-Svobodová, H., Wray, D. S. (2011). Surprisingly small increase of the sedimentation rate in the floodplain of Morava River in the Strážnice area, Czech Republic, in the last 1300 years. - Catena, 86, 3, 192-207. https://doi.org/10.1016/j.catena.2011.04.003

Matys Grygar, T., Sedláček, J., Bábek, O., Nováková, T., Strnad, L., Mihaljevič, M. (2012). Regional contamination of Moravia (south-eastern Czech Republic): Temporal shift of $\mathrm{Pb}$ and $\mathrm{Zn}$ loading in fluvial sediments. - Water, Air, and Soil Pollution, 223, 2, 739-753. https://doi.org/10.1007/s11270-011-0898-2

Nováková, T. (2009). Geochemické a izotopové datování recentních povodňových sedimentů řeky Moravy. - MS, diplomová práce. Univerzita Karlova v Praze. Praha.

Novák, M., Emmanuel, S., Vile, M. A., Erel, Y., Véron, A., Pačes, T., Wieder, R. K., Vaněček, M., Štěpánová, M., Břízová, E., Hovorka, J. (2003). Origin of lead in eight central European peat bogs determined from isotope ratios, strengths, and operation times of regional pollution sources. Environmental Science and Technology, 37, 3, 437-45. https://doi.org/10.1021/es0200387

Ondruch, J., Máčka, Z., Šulc Michalková, M., Putiška, R., Knot, M., Holík, P., Miřijovský, J., Jenčo, M. (2018). Response of channel dynamics to recent meander neck cut-off in a lowland meandering river with artificial training history: the Morava River, Czech Republic. Hydrological Sciences Journal/Journal des Sciences Hydrologiques, 63, 8, 1236-1254. https://doi.org/10.1080/02626667.2018.1474218

Petrová, P., Novák, Z., Havlíček, P. (1998). Výsledky geologických výzkumů v oblasti přírodní památky „Osypané břehy“"v roce 1998. - Zprávy o geologických výzkumech v roce 1998, 32, 116-118.

Petrovský, E., Ellwood, B. (1999). Magnetic monitoring of air- land- and water-pollution. - In: Maher, B., Thompson, R. (eds): Quaternary Climates, Environments and Magnetism, 279-322, Cambridge University Press.

Petrovský, E., Kapička, A., Jordanova, N., Knab, M., Hoffmann, V. (2000). Low-field magnetic susceptibility: a proxy method of estimating increased pollution of different environmental systems. - Environmental Geology, 39, 3-4, 312-318. https://doi.org/10.1007/s002540050010

Wierzbicki, G., Ostrowski, P., Falkowski, T., Mazgajski, M. (2018). Geological setting control of flood dynamics in lowland rivers (Poland). - Science of the Total Environment, 636, 367-382. https://doi.org/10.1016/j.scitotenv.2018.04.250 